\title{
KAJIAN PENANGGULANGAN IUUF PADA PERIKANAN CANTRANG DI LAUT JAWA (WPP - 712)
}

\section{ASSESSMENT IUUF ON DEMERSAL DANISH SEINE FISHERY IN THE JAVA SEA (FMZ - 712)}

\author{
Duto Nugroho' dan Suherman Banon Atmaja ${ }^{2}$ \\ ${ }^{1}$ Peneliti pada Pusat Penelitian Pengelolaan Perikanan dan Konservasi Sumberdaya Ikan \\ ${ }^{2}$ Peneliti pada Balai Penelitian Perikanan Laut \\ Teregistrasi I tanggal: 15 Mei 2013; Diterima setelah perbaikan tanggal: 15 Agustus 2014; \\ Disetujui terbit tanggal: 20 Agustus 2014
}

\begin{abstract}
ABSTRAK
Kajian terhadap perikanan cantrang yang beroperasi di Laut Jawa dengan menggunakan perangkat pengelolaan cenderung dikategorikan sebagai perikanan akses terbuka. Penambahan armada secara historis memperlihatkan rendahnya pertimbangan terhadap pentingnya kelestarian sumber daya ikan, bebas beroperasi dan dalam banyak kasus tidak dikelola sesuai tatalaksana perikanan secara bertanggung jawab. Hasil penelitian menunjukkan sebagian besar armada cantrang dengan izin daerah melakukan penangkapan di luar batas 12 mil laut dan beroperasi di kawasan yang berdasarkan ketentuan diperuntukan bagi nelayan skala kecil yang bukan merupakan wewenang pemberi ijin armada cantrang dari panyai Utara Jawa. Studi kasus dilakukan di Pelabuhan Perikanan Tegal, ditujukan untuk menggambarkan sistem pendataan aktivitas penangkapan yang sedang berjalan. Hal ini berkaitan dengan sistem pencatatan data dan informasi perikanan setempat memiliki kemampuan dan kapasitas terbatas terutama pada sistem pemantauan, pengendalian dan pengawasan untuk melaksanakan pengelolaan perikanan berdasarkan prinsip tata laksana pemanfaatan secara berkelanjutan sesuai peraturan dan keputusan teknis. Terbatasnya pemahaman tentang dampak praktek perikanan tidak berkelanjutan, baik pada tingkat pelaku dan pembuat kebijakan merupakan permasalahan yang harus segera dipecahkan. Kajian ini menyimpulkan bahwa sistem yang berjalan hanya mampu merekam data kurang dari sepertiganya dan penerapan perikanan secara bertanggung jawab pada perikanan cantrang memberikan indikasi pada tingkat yang mengkhawatirkan terutama berdasarkan pertimbangan biologi, eksploitasi dan kelestarian lingkungan, serta memiliki potensi terjadinya unreported yang mengarah pada praktek IUU fishing. Temuan ini diharapkan dapat memperkuat tersedianya landasan pengelolaan perikanan terkait pemulihan sumberdaya ikan demersal bagi kepentingan pengembangan perikanan dalam jangka panjang di Laut Jawa.
\end{abstract}

\section{KATA KUNCI: Kajian, penanggulangan IUU, perikanan cantrang, Laut Jawa}

\begin{abstract}
Study on demersal danish seine fishery operating in the Java Sea tend to be categorized as an open access fishery. The historical fleet development indicate no limited access to exploit demersal fish resources, which is in many cases the fishery are not well managed in a responsible manner. Study indicates that most of license to fish of demersal danish seine operate in areas outside 12 $\mathrm{nm}$, somehow fleets operated in the area for small-scale fishers in the nearby coastal area beyond the origin of license authority. The objective is to describe the existing data collecting system. This corresponds to the limitation of capacity of the catch in one of fishing port. The data collecting system of local fisheries services has a limited capacity, particularly in monitoring, control and surveillance to implement best practices of fisheries management that declared through several technical reference points. Increasing awareness by complying with management measures of business sectors and policy makers must be immediately resolved. This study indicates current system covered less than a third of its landing data and it would affect the implementation of responsible fisheries based on bio-exploitation and environmental sustainability indicators on demersal fishery. It also has a potential on unreported that lead to IUU fishing practices. This should considered that bias of data could affect the accuracy of regular fish stock assessment. This finding should be treated to strengthen the long-term demersal danish seine fishery management plan as a baseline of sustainable demersal fish resources in the Java Sea.
\end{abstract}

\section{KEYWORDS: Assessment, IUU, demersal danish seine fishery, Java Sea}




\section{PENDAHULUAN}

Pemanfaatan sumberdaya ikan demersal secara intensif di Asia Tenggara telah berlangsung sejak diperkenalkannya teknologi pukat hela pada tahun 1960-an oleh Jepang di perairan Filipina yang kemudian berkembang di Negara Asia Tenggara (Morgan \& Staples, 2006). Karakteristik perikanan tangkap di kawasan Asia Tenggara dicirikan oleh aktivitas pengembangan dan pengelolaan pantai yang sangat kompleks (Butcher, 2004) dan pada beberapa kasus terjadi peningkatan upaya yang tidak terkendali sehingga tinjauan secara biologi memberikan indikasi terjadinya kondisi lebih pungut (biological overfishing) (Pauly, 1979). Kelebihan kapasitas penangkapan telah mengakibatkan pengelolaan yang tidak efektif, pengabaian kepatuhan aturan pengelolaan, kerumitan peraturan dan sistem penyelenggaraan pengelolaan yang lemah (Morgan et al., 2007). Keterbatasan kapasitas kepemerintahan tersebut memperbesar peluang terjadinya kekeliruan dan kealpaan pelaporan (Unreported) yang dalam jangka panjang dapat berpengaruh pada terjadinya pemanfaatan sumberdaya ikan secara berlebih sehingga akan menghalangi proses pemulihan sumberdaya ikan dan ekosistem sebagai bagian dari terjaminnya ketahanan pangan (Agnew et al., 2009).

Kajian status pengelolaan perikanan tangkap Indonesia di beberapa perairan berada pada situasi yang sangat dilematis yang diindikasikan bahwa sebagian aktivitas perikanan tangkap telah dimanfaatkan secara penuh (anon, 2011a). Pada sisi lain adanya harapan publik bahwa sektor perikanan harus memberikan kontribusi terhadap peningkatan pendapatan negara melalui peningkatan produksi (Mous et al. 2005) telah berimbas pada kebijakan penambahan jumlah armada penangkapan yang cenderung dilakukan tanpa kendali. Fenomena rendahnya kemampuan pengendalian jumlah armada telah menyebabkan terjadinya mortalitas akibat penangkapan yang cenderung semakin tinggi sehingga berakibat rendahnya kemampuan pulih sumberdaya demersal.

Hal ini juga terjadi secara luas dibeberapa perairan dunia dan umumnya didorong oleh pertumbuhan penduduk, permintaan untuk protein ikan terus meningkat dan sejumlah besar stok ikan dunia saat ini berada pada kondisi yang menurun dan tidak mampu menghasilkan produksi maksimum lestari. Seperti halnya beberapa laporan menyatakan bahwa pengelolaan perikanan selama ini cenderung berkarakteristik kegagalan dibanding keberhasilan. Hal ini terjadi karena lemahnya sistem pengendalian dan pengawasan dan tingginya penguasaan terhadap akses sumber daya ikan sehingga operasi penangkapan berada di bawah tekanan yang cenderung menentang terhadap adanya indikatorindikator penurunan stok.

Fenomena ini mendorong ke arah pemanfaatan berlebih baik secara ekonomi maupun biologi, dan berlangsung hingga mencapai tahapan yang dapat dikategorikan sangat mengancam keberadaan dari beberapa spesies ikan (Berkes, et al., 2001; Cunningham, 2005) dimana pengabaian terhadap keadaan ini akan menimbulkan masalah berat bagi keamanan pangan global di masa depan (Agnew et al., 2007).

Hasil penelitian terdahulu terhadap status pola pemanfaatan sumberdaya ikan demersal di Laut Jawa memberikan peluang terjadinya pertentangan antar berbagai kepentingan para pengguna sumber daya ikan terkait dengan menurunnya kualitas dan kelimpahan sumber daya, kelebihan kapasitas penangkapan ikan dan rendahnya nilai tambah pemanfaatan (Pauly, 1979; Dwiponggo, 1982; Martosubroto \& Badrudin, 1984; Martosubroto 1996). Kajian ini mendeskripsikan beberapa pertimbangan bagi perbaikan sistem pendataan berdasarkan sintesa observasi lapang, aktivitas enumerator, temuan ilmiah dan studi pustaka terkait pengelolaan perikanan cantrang yang berpangkalan di pantai Utara Jawa. Tujuan makalah ini menelusuri penyebab praktek IUU fishing pada perikanan. Oleh karena itu pendekatan pemecahan masalah didekati dengan menggunakan kriteria yang diawali deskripsi sifat dan penyebab dari praktek penangkapan ikan ilegal, seperti dinyatakan dalam Keputusan Menteri Kelautan dan Perikanan no. Nomor kep.50/men/2012 tentang Rencana Aksi Nasional Pencegahan dan Penanggulangan Illegal, unreported, dan unregulated fishing Tahun 2012-2016. Pembahasan diikuti isu yang saling terkait perikanan yang tidak patuh, penangkapan yang tidak dilaporkan dan tidak diatur, serta alternatif pemecahan masalah tersebut.

\section{PERKEMBANGAN PERIKANAN CANTRANG}

Dalam perkembangannya, berdasarkan catatan statistik perikanan tangkap 1977-2012 terlihat bahwa jumlah armada perikanan cantrang di Laut Jawa (WPP 712) menunjukkan peningkatan yang sangat signifikan sebesar kelipatan 15 (Gambar 1). Peningkatan jumlah registrasi armada diduga dilakukan dengan pertimbangan sosial dan ekonomi terkait dengan tingginya permintaan pasar terhadap komoditas ikan demersal yang sebagian besar ditujukan untuk 
kebutuhan industri surimi yang berkembang pada 10 tahun terakhir, dimana Indonesia merupakan salah satu pemasok utama surimi ke Jepang (Sonu, 2002).

Sejak terbitnya Peraturan Daerah No 3/Tahun 2005, Dinas Perikanan dan Kelautan Jawa Tengah menerbitkan izin beroperasinya alat cantrang bagi kapal yang berbobot di bawah 30 GT. Kebijakan ini telah memberi kontribusi terhadap pesatnya perkembangan jumlah alat yang beroperasi di Laut Jawa. Armada cantrang dan sejenisnya yang beroperasi di Laut Jawa memiliki izin yang dikeluarkan oleh pemerintah setempat. Data pelayanan usaha penangkapan ikan (Anon, 2014) memberikan infomasi bahwa armada yang diberikannya izin untuk memanfaatkan ikan demersal hanya bubu dan rawai dasar, sedangkan armada cantrang yang beroperasi memiliki izin penangkapan yang tidak berasal dari kewenangan pemerintah pusat.

Salah satu kendala pengelolaan yang efektif pada perikanan di kawasan negara berkembang adalah dugaan adanya aktivitas perikanan yang tidak dilaporkan, tidak diatur sebagai bagian dari perikanan tidak sah atau lebih dikenal sebagai IUU fishing (Baird, 2004). Rekaman data pendaratan kapal sampling pada tahun 2011 dan 2012 (Tabel 1 dan Tabel 2) memperlihatkan bahwa perkiraan jumlah tawur selama Januari hingga Desember 2011 mencapai 1157 tawur sedangkan pada tahun 2012 diperkirakan sebesar 1.100 tawur. Dengan mengacu pada kapal sampling tersebut dengan kisaran hasil tangkapan antara 240$330 \mathrm{~kg} /$ tawur maka akan didaratkan sejumlah 264363 ton per kapal per tahun.

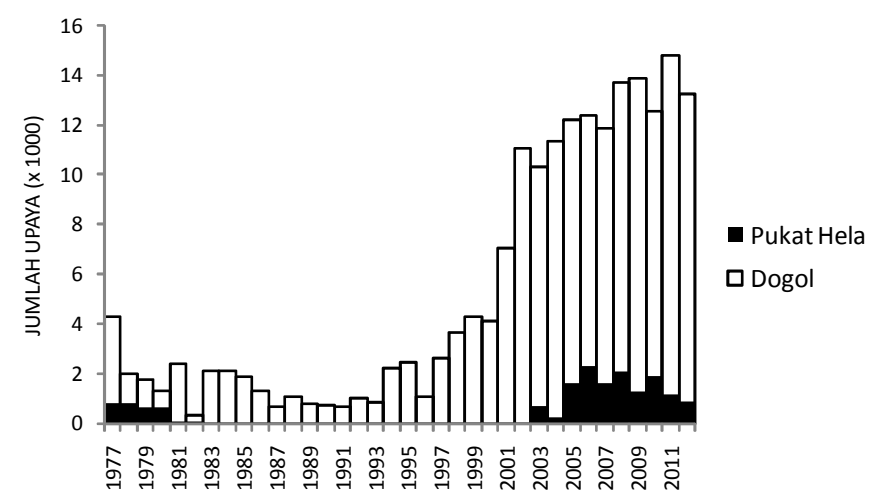

Gambar 1. Perkembangan jumlah pukat hela dan dogol di Laut Jawa 1977-2012).

Figure 1. Number of trawl and demersal danish seine in Java Sea (1977-2012).

Sumber/Source: Anon, (1980-2000); Anon (2001-2013)

Tabel 1. Aktivitas penangkapan kapal cantrang yang diamati pada tahun 2011

Table 1. Fishing activity of demersal danish seine monitored vessel during 2011

\begin{tabular}{ccccccc}
\hline $\begin{array}{c}\text { Trip ke/ } \\
\text { Trip no }\end{array}$ & $\begin{array}{c}\text { Periode 2011/ } \\
\text { Period 2011 }\end{array}$ & $\begin{array}{c}\text { Hari Laut/ } \\
\text { Day at Sea }\end{array}$ & $\begin{array}{c}\text { Hari } \\
\text { efektif/ } \\
\text { Effective } \\
\text { day }\end{array}$ & $\begin{array}{c}\text { Total } \\
\text { setting/ } \\
\text { Total } \\
\text { setting }\end{array}$ & $\begin{array}{c}\text { Hasil tangkapan/ } \\
\text { Catch } \\
\text { (ton/tons) }\end{array}$ & $\begin{array}{c}\text { CPUE/CPUE } \\
\text { (ton/hari/) } \\
\text { (ton/day) }\end{array}$ \\
\hline 1 & 7 Jan - 1 Feb & 26 & 18 & 117 & 31 & 1.19 \\
2 & 11 Feb - 5 Mar & 23 & 18 & 100 & 24 & 1.04 \\
3 & 20 Mar - 16 Apr & 28 & 21 & 110 & 24 & 0.86 \\
4 & 30 Apr - 27 Mei & 28 & 24 & 123 & 28.4 & 1.01 \\
5 & 5 - 28 Juni & 24 & 20 & 131 & 32 & 1.33 \\
6 & 11 Juli - 3 Agust & 24 & 21 & 130 & 33.4 & 1.39 \\
7 & 10 - 23 Agustus & 14 & 11 & 90 & 22.3 & 1.59 \\
8 & 8 - 30 September & 23 & 17 & 119 & 20.8 & 0.90 \\
9 & 15 Okt - 10 Nov & 27 & 20 & 119 & 22.4 & 0.83 \\
10 & 25 Nov - 19 Des & 25 & 17 & 118 & 34 & 1.36 \\
\hline
\end{tabular}

Data pendaratan kelompok ikan demersal dengan jumlah armada di Laut Jawa tercatat sebesar 15591 unit (2011) dan 14.125 unit (2012) dan berdasarkan observasi di dua pelabuhan perikanan pantai memberikan indikasi bahwa hanya $60 \%$ aktif maka diperkirakan hasil tangkapan berada pada kisaran yang cukup besar antara 1,9-3,1 juta ton per tahun sedangkan berdasarkan data statistik perikanan tangkap estimasi pendaratan kelompok ikan demersal sebesar 1,1 - 1,3 juta ton. 
Tabel 2. Aktivitas penangkapan kapal cantrang contoh selama tahun 2012

Table 2. Fishing activity sample of demersal Danish seiner during year 2012

\begin{tabular}{clcccccc}
\hline $\begin{array}{c}\text { Trip ke/ } \\
\text { Trip no }\end{array}$ & $\begin{array}{c}\text { Periode 2012/ } \\
\text { Period 2012 }\end{array}$ & $\begin{array}{c}\text { Hari } \\
\text { Laut/ } \\
\text { Day at } \\
\text { Sea }\end{array}$ & $\begin{array}{c}\text { Hari } \\
\text { efektif/ } \\
\text { Effective } \\
\text { day }\end{array}$ & $\begin{array}{c}\text { Total } \\
\text { setting/ } \\
\text { Total } \\
\text { setting }\end{array}$ & $\begin{array}{c}\text { Hasil } \\
\text { tangkapan/ } \\
\text { Catch } \\
\text { (ton/tons) }\end{array}$ & $\begin{array}{c}\text { CPUE/CPUE } \\
\text { (ton/hari/) } \\
\text { (ton/day) }\end{array}$ & $\begin{array}{c}\text { CPUE/CPUE } \\
\text { kg/tawur }\end{array}$ \\
\hline 1 & 3 - 26 Jan & 23 & 15 & 99 & 32.6 & 2178.6 & 330.1 \\
2 & 8 Feb - 5 Mar & 26 & 20 & 130 & 33.1 & 1651.8 & 253.2 \\
3 & 23 Mar - 18 Apr & 26 & 20 & 138 & 35.6 & 1778.4 & 258.0 \\
4 & 10 Mei - 2 Jun & 23 & 17 & 128 & 32.9 & 1935.2 & 256.9 \\
5 & 19 Juni -8 Juli & 19 & 18 & 130 & 31.8 & 1765.0 & 243.7 \\
6 & 7 Okt - 27 Okt & 20 & 17 & 109 & 26.2 & 1543.5 & 240.7 \\
\hline
\end{tabular}

Perbedaan ini memberikan indikasi adanya sejumlah $0,8-1,8$ juta ton yang tidak tercatat sebagai ikan yang didaratkan. Pengamatan selama tahun 2011 dan 2012 memberikan beberapa sebab terjadinya bias estimasi volume pendaratan tersebut. Faktor yang paling berperan adalah masih rendahnya kepatuhan para pelaku usaha untuk mengisi log-book yang diwajibkan sesuai peraturan Menteri Kelautan dan Perikanan No. 18/2010. Keadan ini diikuti oleh terbatasnya kapasitas pemantauan aktivitas pendaratan hasil tangkapan yang tidak seluruhnya melalui pencatatan di pelabuhan pendaratan ikan. Namun demikian, berdasarkan wawancara terbatas terdapat upaya pelaporan secara berkala terhadap hasil tangkapan yang langsung ditampung di pengolahan, yang disampaikan pada pelabuhan tanpa diikuti proses validasi yang memadai.

\section{STATUS SUMBERDAYA}

Sejak tahun 1975 stok ikan demersal telah dieksploitasi dan cenderung lebih tangkap (Dwiponggo, 1982). Martosubroto \& Badrudin (1984) mengemukakan bahwa di Laut Jawa tidak ada indikasi penurunan beberapa spesies ikan demersal yang digantikan oleh peningkatan spesies lainnya sebagaimana yang terjadi di Teluk Thailand (perubahan komunitas ikan ditunjukan oleh penurunan spesies ikan demersal utama dibarengi dengan peningkatan tren kelompok jenis cephalopoda). Lebih lanjut dinyatakan bahwa laju tangkap dengan kapal survey K.M Mutiara IV setelah pelarangan beroperasinya pukat hela (Keppres 39/80), membuktikan terjadinya peningkatan kelimpahan tersebut tidak terkait dengan faktor lingkungan (musim), tetapi disebabkan peningkatan peremajaan (recruitment) akibat berkurangnya tekanan penangkapan secara drastis selama kurun waktu pelarangan beroperasinya pukat tarik.

Secara umum sumberdaya ikan demersal terdiri dari dua kelompok yaitu kelompok ikan yang berpeluang untuk mencapai ukuran berat $>200$ gram per ekor, sedangkan ikan kecil adalah kelompok ikan yang berat maksimum < 200 gram per ekor. Kajian terhadap status sumberdaya ikan berdasarkan data upaya nominal dan pendaratan pada kurun waktu 1977-20011 memperlihatkan bahwa kelompok jenis ikan demersal berukuran kecil (SD) semakin mendominasi hsil tangkapan yang didaratkan, sedangkan kontribusi ikan demersal berukuran besar (LD) cenderung relatif tidak bertambah. Perubahan kontribusi ikan demersal kecil terjadi setelah tahun 1995 dan semakin menunjukkan kesenjangan terkait dengan banyaknya hasil tangkapan kelompok jenis ikan berukuran kecil (Gambar 2). Perubahan persentase komposisi yang pada awalnya berimbang antara jenis dari jenis ikan berukuran besar (>200 grl ekor) dan yang berukuran kecil ( $<200$ gr/ekor) kemudian setelah tahun 1995 didominasi oleh kelompok ikan berukuran kecil menunjukkan bahwa keragaman sumberdaya ikan demersal bergeser dari tingkat trophik tinggi ke tingkat yang lebih rendah. Berkurangnya keragaman jenis hasil tangkapan jenis ikan yang tergolong predator tingkat tinggi (apex predator) menunjukkan tingkat kesehatan lingkungan sumberdaya ikan demersal yang rendah. Fenomena ini merupakan gejala terjadinya ecosystem overfishing yang berakibat pada rendahnya tingkat keragaman hayati (Pauly et al., 1998; Pauly \& Palomares, 2005; Branch et al. 2010).

Kajian berdasarkan data terbatas terhadap estimasi upaya baku pemanfaatan ikan demersal setara pukat hela dimana indeks daya tangkap pukat hela terhadap cantrang berdasarkan data statistik perikanan tangkap nasional pada tahun 2010-2012 memberikan rasio sebesar 0,3 maka hasil tangkapan pada kurun waktu 2001-2011 memberikan indikasi ambang batas jumlah ikan demersal berukuran besar (LD) yang boleh didaratkan berada pada besaran 62.000 ton sedangkan pendaratan pada tahun 2008 sebesar 70.000 ton kemudian berkurang menjadi 55.000 ton pada tahun 2011. Dengan upaya optimum sekitar 3.100 unit pukat hela atau setara dengan 9.300 unit cantrang. Melihat kecenderungan perkembangan 


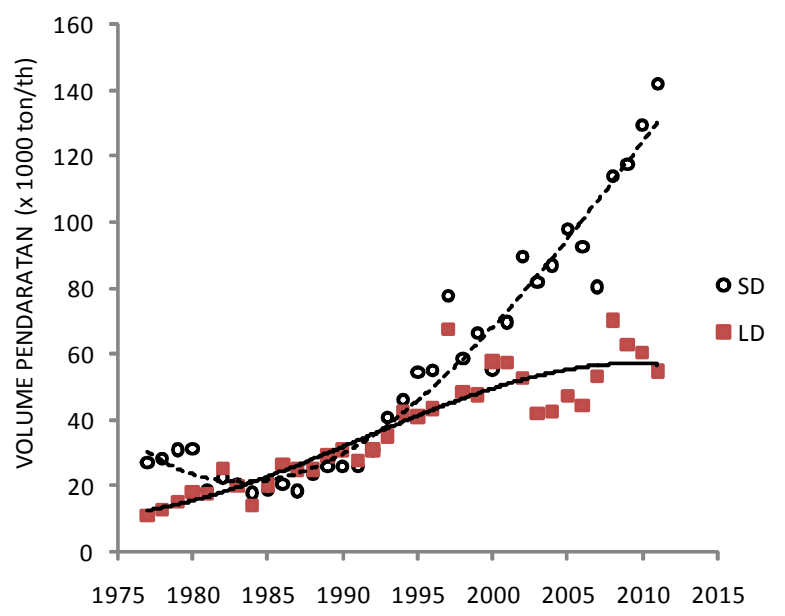

Gambar 2. Perubahan proporsi pendaratan ikan demersal besar (LD) dan kecil (SD) pada kurun waktu 19772011.

Figure 2. Changes in the proportion of large demersal fish landings (LD) and small (SD) in the period 19772011.

armada cantrang selama 5 tahun terakhir yang berada pada kisaran 12.000 unit maka perlu dilakukan penataan ulang kelebihan upaya sebesar 2.700 unit. Status ikan demersal berukuran kecil (SD) juga sudah berada pada keadaan lebih pungut dengan jumlah yang boleh didaratkan sebesar 11.500 ton sedangkan pendaratan telah mencapai volume tertinggi sebesar 13.000 ton pada tahun 2010. Jumlah upaya optimum berada pada besaran 3.900 unit pukat hela atau setara dengan 11.700 unit dengan upaya saat ini sebesar 4.400 unit baku atau setara dengan 13.200 unit cantrang (Gambar 3) maka perlu ditata ulang sejumlah upaya sebesar 1.500 unit.

Mengacu pada alat tangkap yang memiliki selektivitas rendah maka pertimbangan biologi untuk menjaga kelangsungan ikan berukuran besar seharusnya lebih diutamakan, karena kelompok jenis ikan besar mempunyai laju pertumbuhan yang relatif rendah atau berumur panjang sehingga memiliki laju kemampuan pulih rendah.

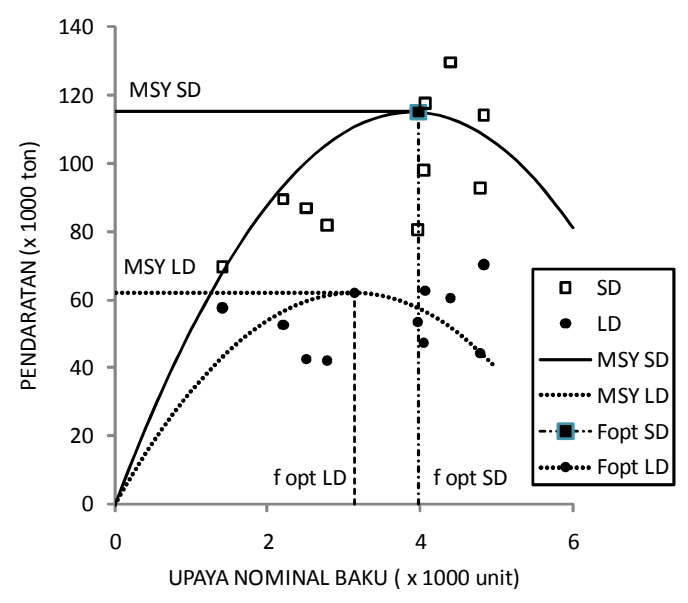

Gambar 3. Indikator volume pendaratan ikan terhadap volume maksimum (MSY) serta upaya saat ini dan upaya optimum (f opt) pendaratan ikan demersal berukuran besar (LD) dan kecil (SD).

Figure 3. Indicators of fish landings volume to maximum volume (MSY) as well as current efforts and the efforts of the optimum (f opt) large demersal fish landings (LD) and small (SD).

\section{STATUS PEMANFAATAN}

Tingkat pemanfaatan ikan demersal di Laut Jawa dapat digambarkan melalui tingginya pertambahan jumlah armada pukat hela dan jenis dogol - cantrang yang terdaftar dengan ukuran kurang dari $30 \mathrm{GT}$ dengan izin yang sepenuhnya diterbitkan oleh pemerintah daerah. Hal ini menunjukkan bahwa tidak 
ada izin penggunaan alat tangkap cantrang yang dikeluarkan oleh Direktorat Pelayanan Usaha Penangkapan Ikan di Laut Jawa (Dit. PUPI-DJPT, 2014). Melihat izin operasi sepenuhnya di luar wewenang pusat maka terkait dengan adanya temuan penelitian yang memberikan indikasi bahwa jumlah armada sudah melebihi jumlah optimum maka rekomendasi tentang perlunya penataan ulang armada yang beroperasi sudah seharusnya menjadi bagian penyusunan kebijakan perizinan pada tataran pemerintah daerah.

Observasi berdasarkan statistik perikanan tangkap tahun 2012, komposisi jumlah kapal yang terdaftar di WPP Laut Jawa berbobot d 10 GT mencapai sekitar $94 \%$, armada dengan kisaran $>10-30$ GT sekitar $4 \%$ dan armada $>30 \mathrm{GT}$ hanya sekitar $2 \%$. Mengacu pada peraturan Menteri KP No. Per 16//Men/2010 tentang pemberian kewenangan penerbitan surat izin penangkapan ikan (SIPI) dan surat izin kapal pengangkut ikan (SIKPI) untuk kapal perikanan berukuran di atas 30 (tiga puluh) gross tonnage sampai dengan 60 (enam puluh) gross tonnage kepada gubernur maka kewenangan pusat hanya tersisa sekitar $1 \%$ pada armada kapal berbobot > $60 \mathrm{GT}$.

Berpijak pada prinsip tata-kelola perikanan secara bertanggung jawab, berbagai perangkat pengelolaan telah diinisiasi oleh lembaga internasional, pada pasal 6, 7 dan 8 (FAO, 1995) dicantumkan bahwa pengelolaan perikanan dikawasan juridiksi nasional harus disusun untuk menghindari terjadinya penurunan sediaan ikan di bawah kemampuan pulihnya agar kelangsungan sumberdaya dapat terjamin (FAO, 2001). Pada beberapa kasus, penyebab IUU pada perikanan dilakukan dalam berbagai bentuk tergantung pada situasi, terutama lemahnya atau hampir tidak adanya sistem untuk pemantauan hasil tangkapan dengan bias yang dapat dipertanggung jawabkan. Salah satu yang umum terjadi pada perikanan yang adalah perubahan teknik penangkapan baik pada alat tangkap maupu alat bantu penangkapan dan tidak tercatat secara lengkap pada data perikanan (Marchal et al., 2007).

Sebagian besar hasil tangkapan dari perikanan cantrang yang didaratkan di pantai Utara Jawa tidak dilakukan pencatatan melalui sistem lelang, tetapi langsung dibawa ke pengumpul dan pengolahan ikan. Upaya memantauan hasil tangkapan telah dilakukan secara intensif oleh petugas Pengawasan Sumberdaya Kelautan dan Perikanan, namun hasilmya masih jauh dari harapan, karena administrator perikanan lokal di tempat pendaratan ikan memiliki tenaga kerja yang terbatas untuk melakukan pemantauan.
Secara umum potensi terjadinya unreported, disreported dan misreported, di pantai Utara Jawa disebabkan oleh faktor faktor sebagai berikut:

1) Setiap pelabuhan/tempat pendaratan ikan yang tersebar luas mempunyai karakteristik berbeda, hal ini menyebabkan kesulitan untuk memantau, mencatat dan melaporkan operasi penangkapan, baik yang beroperasi secara resmi maupun tidak resmi.

2) Administrator perikanan lokal di tempat pendaratan ikan memiliki kemampuan tenaga kerja dengan kapasitas pengetahuan yang terbatas terkait dengan pendataan keragaman jenis ikan sesuai dengan tata laksana perikanan, sehingga estimasi dilakukan dengan mengelompokkan pada jenis ikan pada kategori ikan campur.

3) Adanya aktivitas perikanan yang dilakukan melalui pemindah muatan ke kapal angkut atau transaksi di laut tanpa dibekali dengan sistem pendataan yang memadai. Hal ini menunjukkan pentingnya peran log-book yang telah ditetapkan dan dijalankan namun dengan tingkat ketepatan yang belum dapat divalidasi.

4) Berlangsungnya sistem tangkahan, yang dicirikan oleh sebagian besar hasil tangkapan tidak dilelang, langsung dijual dan tidak dilaporkan atau dilaporkan secara berkala namun tidak dapat diuji $\leq$ ketepatannya.

5) Semi tangkahan, yang dirikan oleh distribusi hasil tangkapan langsung dibawa ke penampung/ pengolahan ikan tanpa dilaporkan sesuai ketentuan.

Pada kasus perikanan cantrang di salah satu Pelabuhan Perikanan Pantai di pantai utara Jawa Tengah, Ernawati et al., (2011) mengemukakan bahwa hasil pencatatan yang dilakukan oleh petugas pengawasan memperlihatkan rata-rata bobot kapal cantrang berkisar antara $24-27 \mathrm{GT}$, dengan ratarata waktu di laut berkisar $20-23$ hari. Observasi tehadap hasil tangkapan per trip berkisar $6,3-8,5$ ton dan CPUE (hari) berkisar $0,31-0,4$ ton. Sementara hasil observer (pencatatan nahkoda) dari kapal cantrang terpilih pada tahun 2011 berkisar antara 21-34 ton, rata-rata durasi di laut berkisar $14-28$ hari dan CPUE (hari) berkisar 0,83 - 1,59 ton. Perbedaan hasil tangkapan cantrang yang dapat memperlihatkan bahwa jumlah ikan yang didaratkan tercatat kurang dari sepertiganya.

\section{DIMENSISOSIO-EKOLOGIS}

Permasalahan alat tangkap cantrang muncul setelah banyaknya kapal pukat cincin beralih menggunakan alat tangkap tersebut dan adanya 
dugaan reduksi bobot dan ukuran kapal. Fakta empiris, di pantai utara Jawa Tengah, beberapa kapal pukat cincin berbobot 30 - 50 GT mulai melakukan perubahan dengan menggunakan alat tangkap cantrang sejak tahun 2003. Suprayoga (2009) melaporkan di Jawa Tengah populasi jaring cantrang makin berkembang pesat, dengan kisaran bobot mulai < 10GT hingga 100 GT yang digunakan untuk mengeksploitasi sumber daya ikan demersal. Anon (2008) mengemukakan bahwa jumlah kapal cantrang di Tegal mencapai 533 unit, separuhnya berasal dari kapal pukat cincin yang telah diubah menjadi kapal cantrang. Di Juwana, jumlah kapal yang berbobot antara 50 GT hingga 80 GT telah menggunakan alat tangkap cantrang sebanyak 87 kapal (Purwadi, 2008), jumlah armada cantrang sudah mencapai sekitar 300 unit, dengan waktu melaut paling lama sebulan dan keuntungan bersih lebih banyak dibanding dengan kapal pukat cincin yang melaut selama tiga bulan (Suprapto, 2009)

Salah satu penyebab yang menimbulkan praktek penangkapan ikan ilegal pada perikanan cantrang biasanya sebagai akibat langsung dari masalah, ekonomi, kelembagaan dan sosial. Masalah ekonomi dapat dikaitkan dengan sifat akses terbuka (open access), sehingga berimplikasi terhadap tingginya persaingan untuk mengeksploitasi sumber daya ikan secara berlebihan tanpa adanya landasan untuk mempertimbangkan kelestariannya; demikian pula dengan meningkatnya permintaan pasar, dan dampak dari hilangnya pendapatan sebagai akibat langsung dari deplesi stok ikan pelagis kecil pada perikanan pukat cincin di Laut Jawa yang kemudian mengubah armada teknologi penangkapan menggunakan cantrang dengan izin yang diterbitkan oleh pemerintah setempat. Pertimbangan sosial termasuk perlu tersedianya lapangan perkerjaan karena pemerintah daerah akan memaksimum kesempatan kerja bagi penduduknya, penyebaran permukiman masyarakat nelayan yang luas; perubahan rezim manajemen tradisional ke manajemen langsung oleh pemerintah. Masalah kelembagaan termasuk undang-undang dan peraturan yang mengatur belum dapat menjangkau dan dipahami oleh penggiat perikanan cantrang skala kecil.

Perikanan cantrang di sepanjang pantai Utara Jawa umumnya termasuk perikanan pesisir dan perikanan lepas pantai. Pada perikanan pesisir, biasanya armada yang digunakan berukuran kurang dari 10 gross ton (GT), serta daerah penangkapan masih terkonsentrasi di sekitar pantai. Perikanan lepas pantai beroperasi dengan kapal yang lebih besar, dengan ukuran lebih dari 10 GT, umumnya mempunyai karakteristik dimensi ekonomi menjadi dominan, karena pelaku perikanan terus mengusung konsep efisensi dan produktivitas, sehingga masalah ekologi kerapkali diabaikan. Pada kenyataannnya kerapkali daerah penangkapan antara perikanan pesisir dengan perikanan lepas pantai tidak dapat dipisahkan secara tegas dan beroperasi secara tumpang tindih di daerah penangkapan yang sama.

\section{PERANGKAT PENGELOLAAN}

Berdasarkan beberapa peraturan perikanan terdapat pembagian kewenangan pengaturan antara pemerintah pusat dan pemerintah daerah. Kewenangan berdasarkan Keputusan Direktur jendral Perikanan Tangkap No. 1760/DPT.O/PI.420.S4/IV/06 tanggal 28 Maret 2006, Gubernur diberikan kewenangan untuk menerbitkan SIUP kepada orang atau badan hukum Indonesia yang melakukan usaha perikanan, SIPI dan/atau SIKPI bagi kapal perikanan yang berukuran di atas $10 \mathrm{GT}$ sampai dengan $30 \mathrm{GT}$, Bupati/Walikota diberikan kewenangan untuk menerbitkan SIUP kepada orang atau badan hukum Indonesia yang melakukan usaha perikanan, SIPI dan/ atau SIKPI bagi kapal perikanan yang berukuran 5 GT sampai dengan 10 GT.

Undang-Undang Republik Indonesia Nomor 1 Tahun 2014 Tentang Perubahan Atas UU Nomor 27 Tahun 2007 tentang Pengelolaan Wilayah Pesisir dan Pulau-pulau Kecil, Pasal 1 angka 7 dinyatakan bahwa 12 mil masih dalam zona wilayah pesisir. Konsekuensinya bahwa wilayah pengelolaan $1 / 3$ bagian dari 12 mil laut teritorial yang menjadi wewenang kabupaten/kota adalah wilayah pesisir. Ketentuan tersebut ditegaskan dalam Pasal 18 angka 1 UU No. 23 Tahun 2014 tentang Pemerintahan Daerah. Pada pasal 18 angka 4 secara substansi kabupaten/kota memiliki wewenang mengelola wilayah pesisir masing-masing. Pembagian urusan bidang Kelautan dan Perikanan terkait dengan pengelolaan ruang laut sampai 12 mil di luar minyak dan gas bumi. Ketentuan ini membuka ruang dan wewenang untuk melakukan izin eksploitasi sumberdaya hayati di kawasan terebut.

Peran Kementerian Kelautan dan Perikanan dengan adanya aturan bahwa Menteri dapat mendelegasikan kewenangan penerbitan perpanjangan SIPI dan/atau SIKPI kepada Gubernur yang diatur pada Peraturan Menteri KP No. Per 16// Men/2010 tentang Pemberian Kewewengan Penerbitkan Surat Izin Penangkapan Ikan (SIPI) dan Surat Izin Kapal Pengangkut Ikan (SIKPI) untuk kapal perikanan berukuran di atas 30 (tiga puluh) gross tonnage sampai dengan 60 (enam puluh) gross tonnage dimana Pasal 2 (1) dinyatakan bahwa Menteri 
memberikan kewenangan penerbitan Surat Izin Penangkapan Ikan (SIPI) dan Surat Izin Kapal Pengangkut lkan (SIKPI) kepada Gubernur untuk kapal penangkap ikan dan kapal pengangkut ikan berukuran di atas 30 (tiga puluh) gross tonnage sampai dengan 60 (enam puluh) gross tonnage.

Kecerdikan para penentu kebijakan dalam memanfaatkan celah akibat kapasitas pengawasan yang terbatas mengindikasikan longgarnya ketentuan perizinan yang telah dikeluarkan. Namun demikian, dalam upaya mengendalikan perkembangan kapal cantrang terutama kapal yang berbobot di atas 30 GT, sesuai Surat Pemberitahuan DJPT Nomor 523.4/ 650 tanggal 17 Juni 2009, tidak memberikan izin baru penggunaan alat cantrang dan tidak memberikan perpanjangan izin penggunaan alat cantrang yang mengalami perubahan ukuran kapal. Kemudian Kementerian Kelautan dan Perikanan memutuskan untuk tetap membatasi penangkapan ikan demersal dengan menggunakan alat tangkap cantrang. Direktorat Jendral Perikanan Tangkap KKP hanya memberikan toleransi kepada 400 kapal yang berbobot di bawah 30 GT, sedangkan untuk kapal yang berbobot di atas 30 GT tetap tidak diperbolehkan.

Namun tekanan dari para pelaku usaha termasuk masyarakat nelayan dan pertimbangan implikasi sosial yang lebih dominan. Masalah mata pencaharian alternatif bagi nelayan sebagai akibat langsung hilangnya pendapatan pada saat deplesi stok ikan pelagis kecil di Laut Jawa dan runtuhnya perikanan pukat cincin semi industri turut berperan dalam menentukan kebijakan peningkatan perizinan perikanan cantrang. Selain itu, bagi pengusaha dan nelayan memiliki latar belakang kehidupan yang tidak mudah keluar dari usaha perikanan tangkap, mereka akan terus berupaya menyesuaikan dengan berbagai strategi meskipun harus menghapi resiko.

Pengamatan terhadap situasi lapangan menunjukkan baik jumlah kapal maupun teknologi penanganan hasil tangkapan terus meningkat, kapal cantrang baru telah dipersiapkan menggunakan metode pembekuan cepat. Kapal motor yang berbobot lebih besar 20 GT, dan umumnya sudah keluar dari pesisir utara Pulau Jawa seperti dikemukakan oleh Ernawati et al., (2011) dan Atmaja \& Nugroho, 2012) dimana armada cantrang pantai Utara Jawa melakukan operasi di daerah penangkapan yang sesuai dengan keadaan cuaca dan pengalaman nakhoda yang secara umum diketahui bahwa daerah penangkapan telah menyebar di hampir seluruh kawasan perairan Laut Jawa, tersebar di perairan Selatan Pulau Bangka - Belitung dan Selatan Kalimantan hingga Selat Makassar.
Kenyataan ini, memperlihatkan rendahnya pemahaman dan tingkat kepatuhan para penyelenggara pengelolaan untuk mengekang kegiatan penangkapan armada cantrang yang beroperasi di luar wilayah 12 mil laut sebagai akibat terbatasnya kemampuan pengendalian pemantauan dan sistem pengawasan dalam melakukan pendataan dengan tingkat kedalaman data yang rendah yang hanya mencatat hasil tangkapan tanpa adanya acuan geografis daerah penangkapan. Hal ini mengakibatkan perikanan beroperasi di perairan khusus disediakan bagi nelayan skala kecil di propinsi lainnya, sehingga fenomena ini secara langsung menggambarkan terjadinya perluasan daerah penangkapan yang telah menimbulkan persaingan ketat untuk memanfatkan sumber daya ikan demersal dengan nelayan pesisir propinsi kawasan Laut Jawa bagian utara.

Dari beberapa kasus tertangkap kapal cantrang oleh aparat keamanan laut yang dipublikasikan oleh media massa, hampir sebagian tuduhan utama adalah pelanggaran jalur penangkapan yang tidak sesuai dengan yang tertera pada dokumen. Nurbiajanti (2008) melaporlan enam kapal cantrang milik nelayan Tegal dan Brebes ditangkap di perairan Bangka. Dua kapal yang berasal dari Juwana terjaring patroli aparat keamanan laut di perairan Timur Bawean (Anonymous, 2009). Pada 19 Juli 2010, tiga kapal cantrang dari Tegal yang berbobot 20 - 30 GT tertangkap oleh aparat keamanan laut di perairan teluk Kumai (Kalimatan Tengah) karena memasuki jalur kurang dari 12 mil, walaupun mereka memiliki surat dokumen lengkap, namun tidak memiliki izin andon (Anonymous, 2010). Pada bulan April 2011, petugas membawa tiga unit kapal cantrang berbobot 27-30 GT yang berasal Kabupaten Tegal, dengan tuduhan telah melanggar jalur penangkapan (memasuki jalur kurang dari 12 mil) (Anon, 2011). Pada kapal yang tertangkap menghadapi konsekuensinya teknis dan ekonomis dimana hasil tangkap dan sebagian bahan bakar diambil paksa oleh nelayan lokal.

Pengelolaan perikanan telah berkembang selama tahun terakhir untuk memecahkan masalah akses terbuka. Berbagai pengendalian, baik ekonomi dan nonekonomi telah digunakan untuk mengendalikan penggunaan sumber daya perikanan tangkap. Berdasarkan kajian terhadap upaya pengelolaan saat ini ditemukan bahwa masih terdapat kelemahan kendati telah tersedia berbagai ukuran pengendalian yang digunakan namun belum berhasil untuk memperbaiki masalah akses terbuka. Perkembangan terakhir memperlihatkan terjadinya perdebatan besar tentang status perikanan yang berpusat pada apakah sumberdaya ikan di lautan bersifat tak terbatas dan dapat habis akibat aktivitas penangkapan yang tidak 
terkendali. Kemajuan teknologi telah diterapkan untuk memenuhi pasokan sumberdaya ikan terkait dengan meningkatnya permintaan global untuk produk ikan yang sejalan dengan pertumbuhan populasi manusia serta didukung berkembangnya jaringan global perdagangan internasional komoditas perikanan. Pertimbangan terhadap keberlanjutan melalui tersedianya rencana pengelolaan perikanan semakin menjadi bagian dari kriteria bagi industry pemasok pasar internasional dan negara.

\section{KESIMPULAN DAN REKOMENDASI KEBIJAKAN Kesimpulan}

Perkembangan aktivitas dan jumlah armada perikanan cantrang di pantai Utara Jawa tidak memperlihatkan adanya pembatasan izin untuk eksploitasi sumberdaya ikan demersal. Aktivitas pemantauan kegiatan penangkapan ikan dari segi kesesuaian sistem perizinan jumlah armada terindikasi masuk ke dalam ranah IUU dimana tingkat kepatuhan pengambil kebijakan telah mengabaikan pentingnya ketersediaan data log-book dengan tingkat bias yang rendah tidak terlaksana sesuai dengan ketentuan yang digambarkan volume hasil tangkapan yang dapat tercatat kurang dari sepertiga dari estimasi pendaratan.

Pengendalian langsung pemerintah melalui penerbitan perangkat pengelolaan melalui peraturan terkait dengan kewenangan administratif, dalam banyak kasus telah gagal untuk menghasilkan perbaikan yang diinginkan. Hal ini tidak terlepas dari tingginya prioritas yang ditujukan untuk mengembangkan sub-sektor perikanan, memberikan manfaat sosial dan ekonomi bagi penduduk, yang sepenuhnya bergantung pada perikanan sebagai sarana mata pencaharian.

Memperhatikan kaidah terkait dengan pentingnya pengelolaan dan konservasi sumberdaya ikan demersal, pengoperasian cantrang belum sepenuhnya mengikuti peraturan Menteri Kelautan dan Perikanan No. 02 tahun 2011, terutama pasal 23 butir 6 terkait penggunaan mata jaring berukuran $>2$ " dan beroperasi di jalur II dan III kecuali bagi armada $<10$ GT dapat beroperasi pada jalur IB atau lebih dari 2 nmil dari garis surut pantai. Dengan demikian habitat dan dasar perairan seluruh perairan pantai di Laut Jawa di dalam batas 2 nmil yang merupakan daerah asuhan seharusnya berdasarkan aturan terbebas dari operasi armada cantrang.

\section{Rekomendasi}

Penataan ulang terhadap kewenangan perizinan yang harus dilengkapi dengan sistem pendataan yang baik mutlak dilakukan melalui penerapan penggunaan log book sesuai ketentuan yang tercantum dalam pasal 4 Peraturan Menteri Kelautan dan Perikanan No.18 tahun 2010 terkait dengan sistem pendataan yang benar.

Penataan kewenangan sistem perizinan cantrang yang sepenuhnya berada di tataran pemerintah daerah dengan bobot < 30 GT perlu dicermati mengingat kapasitas operasional kapal < 30 GT secara teknis akan sangat sulit untuk beroperasi lebih dari 14 hari dan banyak ditemukan armada cantrang yang beroperasi lebih dari 14 hari. Diduga reduksi bobot kapal terjadi pada armada cantrang berukuran mendekati 30 GT.

Penguatan sistem enumerasi data berbasis penelitian pada komoditas yang memiliki arti penting secara ekonomis dan ekologis perlu dukungan melalui kerjasama dengan pemerintah setempat. Tersedianya data secara teratur dengan bias rendah akan berperan nyata dalam proses kalibrasi dan validasi data bagi kepentingan analisis pengkajian sediaan ikan.

Tersedianya rencana pengelolaan perikanan di laut Jawa harus segera dilaksanakan dan dilengkapi dengan acuan yang mudah dipahami oleh para pembuat kebijakan perizinan dan pengendaliannya.

\section{PERSANTUNAN}

Tulisan ini merupakan kontribusi dari kegiatan hasil riset dinamika perilaku pukat cincin di Laut Jawa dan sekitarnya, T.A2010 dan 2011 di Balai Penelitian Perikanan Laut. Muara Baru-Jakarta.

\section{DAFTARPUSTAKA}

Agnew, D.J., J. Pearce, G. Pramod, T. Peatman, R. Watson, J. R. Beddington, T. J. Pitcher. 2009. Estimating the Worldwide Extent of Illegal Fishing. PLoS ONE 4(2): e4570. doi:10.1371/journal.pone.0004570. $8 p$.

Anonymous. 1980-2000. Statistik perikanan tangkap Indonesia, 1977-1998. Disektorat Jenderal Perikanan. Departemen Pertanian Republik Indonesia.

2001-2013. Statistik perikanan tangkap Indonesia, 1999-2012. Direktorat Jenderal Perikanan Tangkap. Kementerian Kelautan dan Perikanan Republik Indonesia.

2011a. Keputusan Menteri kelautan dan perikanan no. 45 tahun 20111 tentang Estimasi Potensi Sumberdaya Ikan Di Wilayah Pengelolaan Perikanan Republik Indonesia. 7 hlm. 
2014. Izin Usaha Perikanan Tangkap. Direktorat Perijinan Usaha Perikanan. Direktorat Jenderal Perikanan Tangkap. Kementerian kelautan dan Perikanan Republik Indonesia.

Atmadja, S.B \& D. Nugroho. 2012. Distribusi Spasial Upaya Penangkapan Kapal Cantrang dan Permasalahannya Di Laut Jawa. J. Lit. Perikan. Ind. Vol.18 No. 4, 233-241 p.

Baird, R. 2004. Illegal, Unreported and Unregulated fishing: AnAnalysis of the illegal, economic and historical factors relevant to its development persistence. Melbourne Journal of International Law. Vol. 5(2): 299-334.

Berkes, F., R. Mahon, P. McConney, R. Pollnack, \& R.Pomeroy, 2001. Managing small-scale fisheries, alternative directions and methods. IDRC. http:// www.idrc.ca $320 \mathrm{pp}$.

Branch, T.A., R. Watson, A. E. Fulton, S. Jennings, C. R. McGilliard, G.T. Pablico, D. Ricard \& S. R. Tracey. 2010. The trophic fingerprint of marine fisheries. Nature. 468. 431-435p.

Butcher, J.G., 2004. The Closing of the Frontier: A History of the Marine Fisheries in Southeast Asia. C. 1850 2000. ISEAS Publication. Singapore. 442 pp.

Cunningham, S. 2005. Successful fisheries management, Issues, Case Studies, and Perspectives. Science 22 June 2007: Vol. 316. no. 5832,1713-1716 pp.

Dwiponggo, A., 1982. Pengkajian Perkiraan Potensi Sumberdaya Perikanan dan TingkatPengusahaannya di Perairan Utara Jawa. Laporan Penelitian Perikanan Laut No. 2369-81 p.

Ernawati, T., Nuruludin \& S.B. Atmaja. 2011. Produktivitas, komposisi hasil tangkapan dan daerah penangkapan jaring cantrang yang berbasis di PPP Tegalsari, Tegal. JPPI Volume 17 (3); 193-200 pp.

FAO, 1999. Code of conduct of Responsible Fisheries. FAO Rome. $49 \mathrm{p}$.

FAO, 2001. What is the Code of Conduct for Responsible Fisheries. FAO Rome. $17 \mathrm{p}$.

Marchal, P., B. Andersen, B. Caillart, O. E. Guyader, H. Hovgaard, A. Iriondo, F. Le Fur, J. Sacchi, \& M. Santurtu'n, 2007. Impact of technological creep on fishing effort and fishing mortality, for a selection of European fleets. ICES Journal of Mar. Sci. 64 (1) 192$209 \mathrm{pp}$.
Martosubroto, P. \& M. Badrudin, 1984. Notes on the status of the demersal resources off the North Coast of Java. Report of the Fourth Session of the Standing Committee on Research and Development. IPFC. FAO Fisheries Report No. 318:33-36 p.

Martosubroto, P. 1996. Structure and dynamics of the demersal resources of the JavaSea, 1975-1979. Dalam Pauly, D. \& P. Martosubroto. Baseline study of Biodiversity: The fish resources of western Indonesia. DGF-GTZ-ICLARM. ICLARM Study Review. 23:321 pp.

Morgan, G.R. \& D.J. Staples. 2006. The history of industrial marine fisheries in SoutheastAsia. FAO-RAP. Bangkok. $28 \mathrm{pp}$.

Morgan, G. R, D. Staples \& S.F. Smith. 2007. Fishing capacity management and IUU fishing in Asia. AsiaPacific Fishery Commission FAO of The United Nations Regional Office forAsia and the Pacific. Bangkok. RAP publication 2007/16. 28 pp.

Mous, P.J., J.S. Pet, J.S., Z. Arifin, R. Djohani, M.V. Erdmann. A. Halim, M. Knight, L. Pet-Soede \& I.G. Wiadnya. 2005. Policy needs to improve marine capture fisheries management and to define a role for marine protected areas in Indonesia. Fisheries Ecology and Management. Vol. 12 (4), 259-268 p.

Nurbiajanti, S. 2008. Enam Kapal Nelayan Tegal Ditangkap di Bangka. http://kompas.com, 5 Mei 2008.

Pauly, D. 1979. Biological overfishing of Tropical Stocks. ICLARM Newsletter 2(3): 3-4 p.

Pauly, D., V. Christensen, J. Dalsgaard, R. Froese, \& F.J. Torres. 1998. Fishing down marine food webs. Science. $279,860-863 p$.

Pauly, D. \& M. L. Palomares. 2005. Fishing down marine food web: it is farmore pervasive than we thought. Bull. Mar. Sci. 76, 197-211 p.

Suprapto, N., 2009. Cantrang Lebih Untungkan Nelayan. http://kompas.com Senin, 20 April 2009. Diunduh 15 Agustus 2013

Suprayogo, J., 2009. Dilema Jaring Cantrang. Kompas., 18 Mei 2009. http://content.kompas.realviewusa.com/ djvu/Kompas/JawaTengah/18-May-2009, diunduh 15 Agustus 2013.

Sonu, S.C. 2002. Surimi Supply, Demand and Market of Japan. NOAA technical memorandum. NOAA-TMNMFS-SWR-039.73p. 